\title{
JEDNOLITOŚĆ PRAWA UNII EUROPEJSKIEJ A JEGO WIELOJĘZYCZNOŚĆ. PRZYPADEK JĘZYKA HISZPAŃSKIEGO
}

\section{Specyfika pozycji języka hiszpańskiego w Unii Europejskiej}

W prawie Unii Europejskiej obowiązuje zasada równorzędności języków narodowych, zgodnie z którą każdy uznawany jest za tak samo autentyczny. ${ }^{1} \mathrm{Na}$ tle pozostałych języków europejskich hiszpański znajduje się jednak w sytuacji wyjątkowej. $Z$ jednej strony, to drugi najważniejszy język ojczysty na świecie: ustępuje pod tym względem wyłącznie chińskiemu mandaryńskiemu, za to wyprzedza język angielski. Tym samym hiszpańska wersja unijnego prawa odgrywa istotną rolę jako główny punkt odniesienia dla dużej liczby faktycznych lub potencjalnych adresatów tego prawa, niekoniecznie będących obywatelami UE.

Z drugiej strony, hiszpański jest dopiero czwartym językiem UE (po angielskim, niemieckim i francuskim): zarówno wtedy, gdy będziemy brać pod uwagę liczbę osób posługujących się nim wyłącznie jako językiem ojczystym, jak i wtedy, gdy dodatkowo uwzględnimy osoby, dla których jest on drugim językiem, czyli głównym językiem obcym. ${ }^{2}$ Natomiast w przeciwieństwie do angielskiego, niemieckiego i francuskiego, hiszpański nie jest uznawany za język roboczy Unii Europejskiej. W wyniku kompromisu zawartego na początku lat 90. to w tamtych trzech językach przygotowywana jest większość roboczych wersji dokumentów prawa unijnego służących za podstawę do prowadzenia negocjacji i prac redakcyjnych.

Z trzech języków roboczych UE hiszpańskiemu zdecydowanie najbliżej jest do francuskiego. Oba języki należą do tej samej grupy języków romańskich, czyli mają wspólne korzenie w łacinie, co z kolei przekłada się na wysoką zbieżność

\footnotetext{
1 Na przykład art. 55 wersji skonsolidowanej Traktatu o Unii Europejskiej (czyli tzw. Traktatu z Lizbony) ma następujące brzmienie: „Niniejszy Traktat został sporządzony w jednym oryginalnym egzemplarzu w językach angielskim, bułgarskim, czeskim, duńskim, estońskim, fińskim, francuskim, greckim, hiszpańskim, irlandzkim, litewskim, łotewskim, maltańskim, niderlandzkim, niemieckim, polskim, portugalskim, rumuńskim, słowackim, słoweńskim, szwedzkim, węgierskim i włoskim, przy czym teksty w każdym z tych języków są na równi autentyczne".

2 Europeans and their Languages, „Special Eurobarometer” June 2012, 386.
} 
pod względem gramatyki i słownictwa. Hiszpański i francuski odnotowują wysoki poziom tzw. podobieństwa leksykalnego (ang. lexical similarity), na poziomie $0,75{ }^{3}$

Niemniej na przestrzeni ostatnich dwóch dekad obserwuje się osłabienie roli języka francuskiego, przy jednocześnie zdecydowanym wzmocnieniu pozycji angielskiego, gdy chodzi o poziom roboczy prac nad dokumentami prawa UE (rysunek 1). A z językiem angielskim hiszpański nie odnotowuje już takiej zbieżności leksykalnej, należą bowiem do dwóch różnych grup językowych. Gramatyczna i leksykalna rozbieżność dwóch języków przekłada się, z zasady, na większe problemy w dokładnym tłumaczeniu tekstów z jednego języka na drugi. Tym samym słabnąca pozycja francuskiego pośród trzech unijnych języków roboczych powinna oznaczać większe ryzyko tego, że podczas przekładu unijnych dokumentów na hiszpański pojawią się błędy lub niejednoznaczności.

\section{Rysunek 1. Języki, w których powstają wstępne wersje dokumentów unijnych}

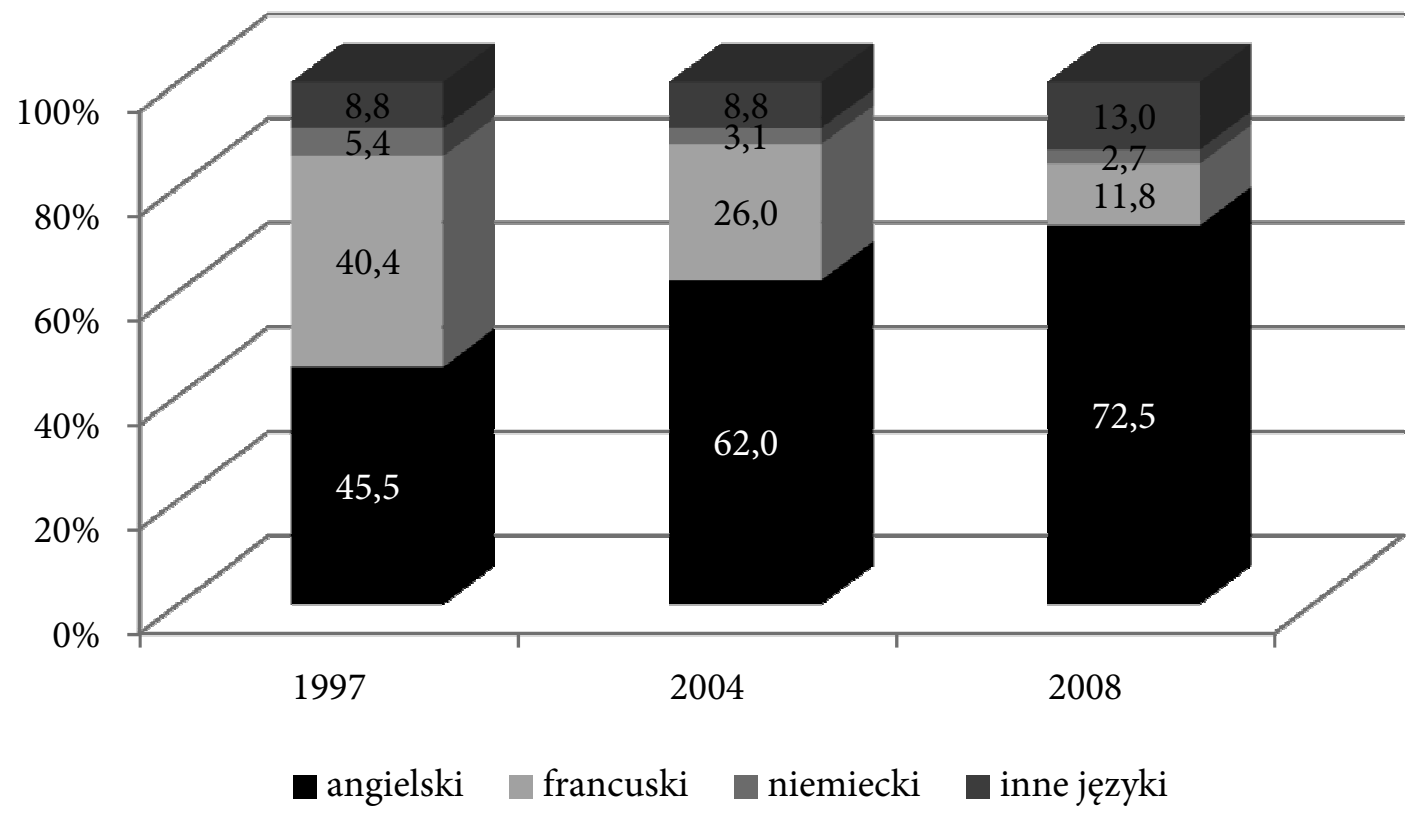

Źródło: Translating for a Multilingual Community, European Commission 2009.

To, że wszystkie wersje językowe dokumentów unijnych uznawane są za tak samo autentyczne ma silne uzasadnienie w zasadzie demokratycznego dostępu obywateli unijnych do prawa. ${ }^{4}$ Niemniej sytuacja ta spotyka się z rosnącą krytyką, zwłaszcza po przystąpieniu do UE dwunastu nowych państw członkowskich. Akcesy z lat 2004 i 2007 znacznie skomplikowały prace tłumaczeniowe, zwiększając ich zakres

3 Ethnologue: Languages of the World, red. P. Lewis, Dallas 2009, www.ethnologue.com

4 Nowa strategia ramowa w sprawie wielojęzyczności, Komisja Europejska, 22 listopada 2005. 
oraz koszt. W 2011 roku 2500 tłumaczy „wyprodukowało” 2,2 mln stron dokumentów. ${ }^{5}$ Przed 1 maja 2004 roku tłumaczy było o połowę mniej (1300), a nakład pracy niższy o jedną trzecią (1,3 mln stron rocznie). ${ }^{6}$ To wszystko oznacza rosnące koszty tłumaczeń, jednakże jeszcze poważniejszym problemem jest zwiększanie się ryzyka wystąpienia rozbieżności pomiędzy poszczególnymi wersjami językowymi unijnych dokumentów, co z kolei może spowolnić proces wydawania orzeczeń przez Europejski Trybunał Sprawiedliwości w razie gdyby doszło do niejasności w interpretacji konkretnych aktów prawnych.

Dlatego coraz częściej pojawiają się opinie, że zasada efektywności unijnego prawa powinna mieć pierwszeństwo przed zasadą równorzędności języków. Niektórzy postulują, aby najważniejsze unijne akty prawne nadal były tłumaczone na wszystkie języki narodowe, ale bez konieczności uznawania wszystkich wersji za jednakowo autentyczne. W trwającej od lat dyskusji pojawiają się pomysły tak egzotyczne, jak powrót do łaciny albo wykorzystanie esperanta jako języka bazowego UE. Na tle tych pomysłów jak głos rozsądku brzmi pomysł potraktowania języka angielskiego jako jedynego punktu odniesienia. ${ }^{7} \mathrm{~W}$,"The Economist” zauważono, iż „w coraz bardziej wielojęzycznej Unii, coraz wyraźniej widać, że istnieje tylko jeden język". Potwierdzają to badania Eurobarometru z marca 2012 roku (rysunek 2). ${ }^{9}$ Zgodnie z nimi angielski jest najpopularniejszym językiem obcym wśród obywateli UE. Posługuje się nim płynnie 38\% mieszkańców. Proporcja ta nie uległa zmianie $\mathrm{w}$ porównaniu $\mathrm{z}$ rokiem 2005. Osłabła natomiast w tym okresie pozycja francuskiego (z 14\% do 12\%) i niemieckiego (z 14\% do 11\%). Można zatem sobie wyobrazić, że w przyszłości to wersja angielska uznana zostanie za rozstrzygającą w przypadku jakichkolwiek niejasności podczas interpretacji unijnego prawa.

Do tej pory Hiszpania zdecydowanie broniła pozycji swojego języka w unijnym prawie. Wspólnie z Włochami przez długi czas blokowała, właśnie ze względów językowych, przyjęcie systemu patentu europejskiego, który miał dopuszczać trzy języki oficjalne: angielski, francuski i niemiecki. Obecnie oba kraje pozostają poza tym systemem, przyjętym przez pozostałe 25 państw członkowskich w 2012 roku według formuły „,wzmocnionej kooperacji”.

\footnotetext{
5 Brussels and the translators shortage, „Presseurop” August 8, 2012.

6 Dilemas en la Torre de Babel, „BBC Mundo.com” April 22, 2004.

7 Ibidem; a także S. Kurpas, El reto de alcanzar un equilibrio, „El Pais” 8 enero 2006 oraz A. Glezl, Lost in Translation: EU and the Official Languages - Problem of the Authentic Text, Comenius University in Bratislava 2007.

8 Babelling on: How more official languages could eventually mean less diversity, „The Economist” December 13, 2006.

9 Europeans and their Languages, op.cit.
} 
Rysunek 2. Języki, w których obywatele UE potrafią posługiwać się w stopniu pozwalającym na konwersację (w \%)

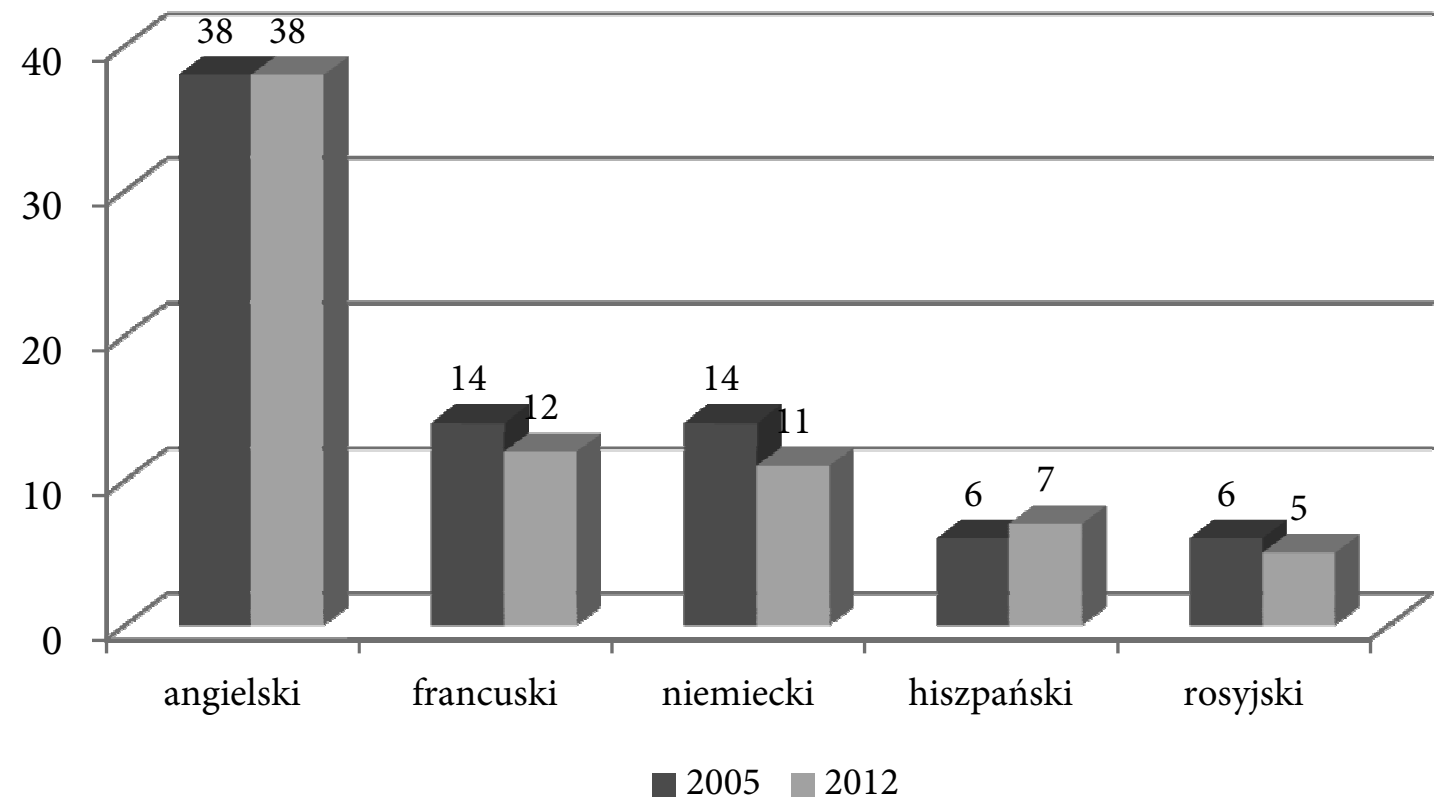

Źródło: Europeans and their Languages, „Special Eurobarometer” June 2012, 386.

Natomiast Hiszpania nie zabiegała o włączenie hiszpańskiego do grupy języków roboczych UE. Prawdopodobnie rządy w Madrycie zdawały sobie sprawę $\mathrm{z}$ tego, że gdyby wyszły z tego typu inicjatywą, w ślad za nimi poszłyby Włochy, a potem Polska (jako największe z nowych państw członkowskich) oraz, być może, niektórzy płatnicy netto do unijnego budżetu, jak Holandia czy Szwecja. Zapewne Hiszpanie wiedzą również, że sam nieformalny status języka roboczego UE niewiele znaczy, o czym świadczy znikome wykorzystanie niemieckiego podczas opracowywania dokumentów unijnych.

Aktualna sytuacja gospodarcza i polityczna, w jakiej znalazł się rząd Mariano Rajoya, sprawia, że Hiszpania może okazać się bardziej przychylna w stosunku do ewentualnego pomysłu uznania angielskiego za punkt odniesienia dla pozostałych wersji językowych prawa UE, a zatem ustanowienia tylko jednej wersji autentycznej. Dzieje się tak z dwóch powodów. Po pierwsze, takie rozwiązanie może przynieść konkretne oszczędności budżetowe. Po drugie, Madryt zmaga się z nasileniem presji regionów na poszerzenie autonomii - nie jest więc w jego interesie wspieranie polityki różnorodności językowej, która doprowadziła do tego, że hiszpańskie środki publiczne są przeznaczane na tłumaczenie unijnego prawa na kataloński, baskijski i galicyjski. 


\section{Wielojęzyczność a jednolitość prawa Unii Europejskiej - problem przekładu}

Wspomniano już o tym, że wzrost znaczenia angielskiego, a osłabienie francuskiego pośród roboczych języków UE może doprowadzić do pogłębienia się problemu przekładu prawa unijnego na język hiszpański. Należy jednak pamiętać o tym, że język stosowany w dokumentach prawnych znacznie różni się od języka potocznego, charakteryzując się większym poziomem sformalizowania i uporządkowania, a co za tym idzie większą przewidywalnością. To pozwala na bardziej „mechaniczne” tłumaczenie tekstów prawnych z jednego języka na drugi. Co więcej, większość krajów europejskich wpisuje się w tę samą tradycję prawną, co przekłada się na względną równoważność stosowanych w nich form nakazu (musi), zakazu (nie wolno), powinności (powinien) czy przyzwolenia (może), które potencjalnie mogłyby nastręczać najwięcej problemów tłumaczeniowych i interpretacyjnych.

Kwestia rozbieżności leksykalnej dwóch języków ulega w prawie unijnym dodatkowemu „rozmyciu” dzięki temu, że Brukseli udało się na przestrzeni ostatniego półwiecza wykształcić specyficzną nowomowę. Słowa i wyrażenia stosowane w tekstach unijnych są często neologizmami w każdym z języków europejskich, co niweluje problemy związane z różną interpretacją odmiennych wersji językowych, pozwalając na tym większą dozę automatyczności w procesie tłumaczenia.

Mimo to historia stosowania prawa unijnego zna przypadki, gdy rozbieżności występujące $\mathrm{w}$ różnych wersjach językowych odegrały istotną rolę w interpretacji konkretnych dokumentów prawa UE. ${ }^{10}$ Zwłaszcza trzy kwestie decydują o możliwości wystąpienia niespójności lub wieloznaczności pomiędzy różnymi wersjami językowymi unijnych dokumentów. Po pierwsze, odmienne mogą być zakresy znaczeniowe słów i wyrażeń, które w dwóch różnych językach sobie odpowiadają. Po drugie, różne mogą być zasady i zwyczaje dotyczące stosowania ważnych w prawie czasowników modalnych. Po trzecie wreszcie, mogą wystąpić różnice w składni lub semantyce zdań, rzutujące na sposób rozumienia całych wypowiedzi.

\subsection{Nowomowa}

Instytucje unijne słyną z tego, że stosują specyficzne słownictwo, z częstymi neologizmami. To może sprawiać trudność tłumaczom - np. wówczas, gdy muszą podjąć

10 Przegląd spraw, w których Europejski Trybunał Sprawiedliwości musiał zmierzyć się z kwestią rozbieżności w różnych wersjach językowych prawa unijnego, przedstawia m.in. A. Glezl, op.cit. 
decyzję, czy nowe wyrażenie przekładać na własny język dosłownie, opisowo, w formie metafory, czy zachowując obcojęzyczny oryginał. Niemniej wydaje się to problemem mniejszej wagi z punktu widzenia interpretacji różnych wersji językowych prawa unijnego. W reakcji na neologizmy (angielskie, francuskie, niemieckie) dość szybko pojawiają się i utrwalają odpowiadające im neologizmy w innych językach.

Dobrze ilustruje to przypadek angielskiego rzeczownika greening, który bywa stosowany w dwóch znaczeniach: zmniejszania szkodliwego wpływu (czegoś) na środowisko lub uwzględniania kwestii ekologicznych w jakiejś polityce czy działaniu instytucji. W języku hiszpańskim w obu sytuacjach przyjęło się używać neologizmów ecologización, enverdecimiento oraz reverdecimiento, aczkolwiek zaleca się także rozważenie tłumaczeń opisowych, takich jak hacer(se) más ecológico/verde. ${ }^{11}$

Podobnie przedstawia się historia francuskojęzycznego wyrażenia fraude carrousel, tłumaczonego na polski dosłownie jako „oszustwo karuzelowe”. Ze względu na to, że w języku hiszpańskim oba składające się na to wyrażenie słowa są bardzo zbliżone do wersji francuskiej, wyrażenie to przyjęło analogiczną formę: fraude carrusel. Niemniej zwraca się uwagę na to, że w hiszpańskim istniały wcześniej już dwa inne wyrażenia, fraude en cadena („oszustwo łańcuchowe”) oraz fraude de la trucha („oszustwo na pstrąga”), mające analogiczne znaczenie. ${ }^{12}$

\subsection{Zakresy znaczeniowe (pola semantyczne)}

Problemy z tłumaczeniem tekstów pojawiają się nawet wówczas, gdy dotyczą języków bardzo względem siebie bliskich, tak jak w przypadku hiszpańskiego i portugalskiego, wykazujących podobieństwo leksykalne na poziomie $0,89 .{ }^{13}$ Dobrze ilustruje to historia dokumentu zwołującego na 24 sierpnia 2012 roku nadzwyczajne zebranie Rady Stałej Organizacji Państw Amerykańskich (OPA) w związku ze sporem Ekwador-Wielka Brytania o azyl dyplomatyczny dla szefa Wikileaks, Juliana Assange’a. Tekst hiszpański przewidywał, że przedstawiciele państw spotkają się po to, aby „uzgodnić środki, jakie należy podjąć [w tej sprawie]” (hiszp. acordar las medidas que convenga adoptar). Choć w języku portugalskim istnieje sformułowanie lustrzane względem wersji hiszpańskiej, może ono być inaczej interpretowane. Zgodnie $\mathrm{z}$ argumentacją brazylijskiego przedstawiciela przy OPA portugalskie acordo mogłoby sugerować, że podczas spotkania dojdzie do przyjęcia formalnego dokumentu, prawnie wiążącego, który musiałby zostać podpisany przez wszystkich

11 Guía del Departamento de Lengua Española. II: Problemas y dudas de traducción, Dirección General de Traducción, Comisión Europea, agosto 2010, s. 115.

12 Ibidem, s. 162.

13 Ethnologue..., op.cit. 
zgromadzonych. Dlatego strona brazylijska wprowadziła poprawkę do portugalskiej wersji tekstu, stosując mniej zobowiązującą formułę „dojść do porozumienia” (port. chegar a um entendimento). ${ }^{14}$

Powyższy przypadek demonstruje problemy, jakie mogą wynikać z niejednolitości pól znaczeniowych pozornie odpowiadających sobie słów lub wyrażeń z dwóch różnych języków. Czasami drobne różnice między takimi wyrazami mogą być, $\mathrm{z}$ formalnego punktu widzenia, na tyle istotne, aby daną parę wyrazów uznać za homonimy (tj. tzw. fałszywych przyjaciół - ang. false friends). Unijny Przewodnik tłuma$c z a,{ }^{15}$ przygotowany przez Departament Języka Hiszpańskiego w Dyrekcji Generalnej ds. Tłumaczeń Komisji Europejskiej, wymienia kilka przykładów występowania tego typu problemu podczas przekładu z języka angielskiego na hiszpański.

Dotyczy to wyrażenia in line with, tłumaczonego na polski jako "zgodnie z” i posiadającego, wydawałoby się, oczywisty hiszpański odpowiednik en linea con. Niemniej hiszpańskie sformułowanie nabrało w połowie XX wieku znaczenia przenośnego i zazwyczaj oznacza „podążając w ślad za”. Dlatego, tłumacząc angielskie in line with, zaleca się stosować inne hiszpańskie sformułowania, takie jak de acuerdo con, con arreglo a, en consonancia con, conforme a, de conformidad con, ajustado a albo en coherencia. ${ }^{16}$

Podobnie dzieje się $\mathrm{z}$ angielskim słowem including, tłumaczonym na polski jako „włączając w to", a posiadającym w hiszpańskim wygodny, wydawałoby się, odpowiednik incluyendo. Jednak autorzy słowników angielsko-hiszpańskich odradzają stosowanie tego słowa, uznawanego przez nich za upraszczający anglicyzm. Zależnie od kontekstu, słowo including można przetłumaczyć, używając jednego z szerokiej gamy słów lub wyrażeń języka hiszpańskiego, m.in.: entre ellos, como por ejemplo, incluso, sin olvidar, hasta, especialmente, principalmente lub en especial. ${ }^{17}$

Gustavo Silva zwraca uwagę na wiele pułapek językowych w unijnych dyskusjach na temat zdrowia publicznego. ${ }^{18} \mathrm{~W}$ przekładzie $\mathrm{z}$ angielskiego na hiszpański problematyczne jest już samo słowo zdrowie (ang. health), które nie we wszystkich kontekstach można przetłumaczyć przy użyciu hiszpańskiego la salud. W przypadku, gdy występuje ono jako rzeczownik, dopuszczalne są wersje sanidad (sektor zdrowia),

14 Historia ta została opisana $\mathrm{w}$ artykule C. Assange, Ecuador y Reino Unido dispuestos a hablar, pero no varian sus posiciones, „Infolatam” 21 agosto 2012.

15 Guía del Departamento..., op.cit.

16 Ibidem, s. 126.

17 Ibidem, s. 128.

18 G. Silva, Algunas dificultades de la traducción del inglés al español en el campo de la salud pública [referat wygłoszony podczas konferencji w Departamencie Języka Hiszpańskiego Dyrekcji Generalnej ds. Tłumaczeń w Komisji Europejskiej, 10 marca 2010, tekst referatu dostępny w serwisie:] Punto y Coma, http://ec.europa.eu/translation/bulletins/puntoycoma/121/pyc1215_es.htm 
salubridad (zdrowotność) albo higiene (higiena). W funkcji przymiotnika możliwe są formy sanitario (sanitarny), higiénico (higieniczny), médico (medyczny), salubre (zdrowy), salutífero (zbawienny) albo de enfermedad (chorobowe). Powyższe formy mogą być też stosowane w funkcji przysłówka, choć coraz częściej używa się pasującego wszędzie tłumaczenia dosłownego de la salud.

Ciekawy jest też przypadek angielskiego wyrażenia infant mortality, ${ }^{19}$ którego nie można tłumaczyć wprost jako mortalidad infantil, gdyż odmienne są pola znaczeniowe angielskiego infant (niemowlę) i hiszpańskiego infante (dziecko). W tym drugim przypadku może chodzić nawet o dziecko siedmioletnie! Dlatego zaleca się, aby infant mortality tłumaczyć jako mortalidad de menores de 1 año (umieralność wśród dzieci poniżej roku życia), zgodnie z definicjami przyjętymi w epidemiologii. Analogicznie, wyrażenie child mortality powinno być tłumaczone jako mortalidad de menores de 5 años (umieralność wśród dzieci poniżej 5 roku życia).

\subsection{Czasowniki modalne}

Zastosowanie czasowników modalnych uznawane jest za najbardziej problematyczne podczas porównywania dwóch wersji językowych tego samego dokumentu. Jak wynika ze studium Sørena Brandta, ${ }^{20}$ czasownikom modalnym występującym w różnych językach odpowiadają „zachodzące na siebie zakresy znaczeniowe” (ang. overlapping ranges of meaning), przez co czasowniki te nie mogą być uznawane za ekwiwalenty translacyjne. Co więcej, jak wskazano już w tym opracowaniu, poszczególne wyrażenia modalne często nie mają jednego, stabilnego znaczenia. Przez to czasownikom modalnym w jednym języku mogą odpowiadać różne warianty $\mathrm{w}$ innym języku, zależnie od tego, jakie znaczenie przyjmuje zdanie $\mathrm{w}$ danym kontekście - np. zdanie „Piotr musi mieszkać w Paryżu” może oznaczać zarówno nakaz, jak i przypuszczenie. ${ }^{21}$

Tabela 1, stanowiąca rozwinięcie tabeli modalności Brandta, uwidacznia problem nakładania się pól znaczeniowych różnych odpowiedników czasowników posiłkowych.

Wiele czasowników języka hiszpańskiego (np. deber, poder) powtarza się jako odpowiedniki różnych czasowników angielskich. Po części wynika to stąd, że w języku hiszpańskim istotny jest nie tylko odpowiedni czasownik, ale też czas lub tryb, w jakim zostanie użyty. Przykładowo, czasownik ang. should tłumaczy się z zasady w czasie teraźniejszym, stosując formy debe, conviene albo es oportuno.

19 Ibidem.

20 S. Brandt, Modal Verbs in Danish, C.A. Reiutzel, Copenhagen 1999.

21 Ibidem. 
Jedynie w rekomendacjach dopuszczalne jest wykorzystanie trybu przypuszczającego debería. Natomiast nie można tłumaczyć should w czasie przyszłym. Forma deberá odpowiada angielskiemu shall, typowemu dla rozporządzeń w dokumentach prawnych. Czasownik deber w czasie teraźniejszym jest też stosowany przy tłumaczeniu angielskiego $m u s t,{ }^{22}$ co przypomina o większej niż by się z pozoru wydawało zbieżności znaczeniowej czasowników must i should w języku angielskim (przynajmniej gdy chodzi o ich wykorzystanie w dokumentach prawnych).

Tabela 1. Znaczenia czasowników modalnych języka angielskiego i hiszpańskiego

\begin{tabular}{|c|c|c|}
\hline Typ modalności/Język & Angielski & Hiszpański \\
\hline Abilitywna & $\begin{array}{l}\text { Can } \\
\text { Have to } \\
\text { Need }\end{array}$ & $\begin{array}{l}\text { Poder } \\
\text { Ser capaz de } \\
\text { Tener que } \\
\text { Deber } \\
\text { Necesitar }\end{array}$ \\
\hline Deontyczna & $\begin{array}{l}\text { May } \\
\text { Shall } \\
\text { Ought to } \\
\text { Should }\end{array}$ & $\begin{array}{l}\text { Poder } \\
\text { Deber } \\
\text { Deber } \\
\text { Deber } \\
\text { Tener que } \\
\text { Convenir } \\
\text { Ser oportuno } \\
\text { Proceder } \\
\text { Deber }\end{array}$ \\
\hline
\end{tabular}

Źródło: Opracowanie własne na podstawie kategoryzacji czasowników modalnych Sørena Brandta w: S. Brandt, Modal Verbs in Danish, C.A. Reitzel, Copenhagen 1999, s. 30-32.

Istnieją specyficzne wyrażenia, w których przypadku czasownik should przybiera odmienną, ale ustandaryzowaną formę. Dotyczy to zwłaszcza sformułowania (Decision/Directive/Regulation...) should therefore be amended accordingly, często występującego w unijnych aktach prawnych. Oficjalnie przyjęto zasadę, że w języku hiszpańskim tłumaczone jest ono jako Procede, por tanto, modificar (la Decisión/la Directivalel Reglamento...) en consecuencia. ${ }^{23}$

22 Guía del Departamento..., op.cit., s. 220.

23 Ibidem, s. 70. 


\section{Pragmatyka językowa}

Dodatkowa trudność może polegać na tym, że język hiszpański rządzi się inną pragmatyką językową od angielskiego. Jak zauważa Juan Luis Conde, ${ }^{24}$ "Języki to nie tylko słowa. Aby uniknąć tłumaczeń absurdalnych lub po prostu złych, należy uwzględniać zwyczaje [hiszp. los hábitos] każdego języka, które są tak samo różne, jak zwyczaje gastronomiczne poszczególnych krajów".

Przykładowo, angielskie nakazy bywają w hiszpańskim formułowane $\mathrm{w}$ formie zakazów (podobnie zresztą, jak dzieje się w języku polskim). Angielskie keep clear tłumaczone jest jako prohibido aparcar („zakaz parkowania”), a stay away from me jako no te acerques de mí („nie zbliżaj się do mnie”).

Problem dotyczy w szczególności czasowników angielskich to stay i to keep, które teoretycznie mają swój hiszpański odpowiednik mantener, ale jego użycie w dosłownym przekładzie nie jest zalecane. Hiszpański czasownik mantener, w przeciwieństwie do obu czasowników angielskich, ma dodatkowy walor trwania i aktywnego działania. To oznacza, że jego zastosowanie w przekładzie może razić sztucznością, a nawet prowadzić do błędów interpretacyjnych. Przykładowo, angielskie keep this medicine out of children's reach można przetłumaczyć jako mantenga este medicamento fuera del alcance de los niños („lek trzymać z dala od dzieci”), ale wówczas sugeruje się, że musi nastąpić aktywne działanie polegające na niedopuszczaniu dzieci do leku. Tymczasem pragmatycznym odpowiednikiem wersji angielskiej jest w tym wypadku hiszpańskie no deje este medicamento al alcance de los niños („nie pozostawiać leku w miejscu dostępnym dla dzieci”). ${ }^{25}$

\section{Studium przypadku: dyrektywa usługowa}

Porównanie angielskiej i hiszpańskiej wersji językowej pojedynczego dokumentu unijnego (w tym przypadku dyrektywy usługowej ${ }^{26}$ ) pozwala unaocznić pole dla potencjalnych, związanych z przekładem niejasności interpretacyjnych, zarazem

24 J.L. Conde, Castellano doblado. Interferencias del inglés en el castellano contemporáneo, „Punto y Coma" marzo-abril 2011, No. 122, http://ec.europa.eu/translation/bulletins/puntoycoma/122/ index_es.htm

25 Ibidem.

26 Dyrektywa 2006/123/WE Parlamentu Europejskiego i Rady z dnia 12 grudnia 2006 r. dotycząca usług na rynku wewnętrznym. 
jednak zaświadcza o tym, że praktyka tłumaczeniowa stopniowo zmierza ku redukcji tego pola do minimum. W szczególności dotyczy to użycia czasowników modalnych jako nośników nakazu, zakazu, powinności lub przyzwolenia.

Należy przy tym zastrzec, że z punktu widzenia niniejszej analizy nie ma znaczenia, czy hiszpańska wersja dyrektywy usługowej powstała w oparciu o tekst angielski. Szereg niespójności pomiędzy wersją angielską i hiszpańską, powtarzających się w wersji francuskiej, wskazywałby raczej na to, że Hiszpanie w wielu wypadkach korzystali z tej ostatniej, bliższej im językowo wersji. Niemniej już samo wystąpienie rozbieżności pomiędzy dwiema różnymi wersjami językowymi tego samego unijnego dokumentu prawnego świadczy o ryzyku, jakie rodzi system uznający wszystkie wersje za tak samo autentyczne, choć proces powstawania wielu z nich przypomina raczej grę w "głuchy telefon”.

Dyrektywa usługowa, jak wiele dokumentów tego typu, składa się z dwóch łatwo identyfikowalnych części: wstępu oraz treści właściwej. Tym, co zwraca uwagę, jest wyraźnie wyższa regularność w tłumaczeniu treści właściwej, wynikająca zapewne stąd, że konstrukcja tej części dyrektyw jest znacznie bardziej sformalizowana. Dla odmiany, porównując wstęp obu wersji językowych, można dostrzec szereg niespójności.

O ile zasadniczo angielskie should tłumaczone jest przy wykorzystaniu hiszpańskich czasowników deber (debe, deben) haber (hay que, ha de, han de) lub form conviene (que) lub procede (que), zdarzają się wyjątki od tej reguły.

W paragrafie (motywie) 20 preambuły angielskie zdanie: ,The exclusion from the scope of this Directive [...] should apply not only to questions specifically dealt with in these Directives... (polska wersja: „Wyłaczenia z zakresu stosowania niniejszej dyrektywy [...] powinny mieć zastosowanie nie tylko do zagadnień szczegółowo uregulowanych $w$ tych dyrektywach...") zostało przetłumaczone bez użycia czasownika modalnego, w trybie oznajmującym czasu teraźniejszego, tak jakby zdanie wskazywało nie tyle na powinność, ile na prawidłowość dotyczącą zdarzenia: „Las excepciones al ámbito de aplicación de la presente Directiva [...] no solo se aplican a cuestiones tratadas concretamene en esas Directivas...”.

Ten wyjątek można uzasadnić wielością znaczeń, jakie przyjmuje czasownik should w mowie potocznej. Jak pokazują inne przykłady, angielski czasownik should, który w dokumentach prawnych przyjęło się stosować dla wskazania powinności lub zobowiązań, bywa w angielskiej wersji językowej nadużywany: stosowany tam, gdzie wystarczyłby użycie czasownika w trybie oznajmującym czasu teraźniejszego.

Oto inny przykład. W paragrafie 57 angielskie zdanie: „The provisions of this Directive relating to authorisation schemes should concern cases where the access to or exercice of a service activity by operators requires a decision by a competent authority" 
(pol. „Przepisy niniejszej dyrektywy dotyczące systemów zezwoleń powinny obejmować przypadki, w których podjęcie lub prowadzenie działalności usługowej przez podmioty gospodarcze wymaga wydania decyzji przez właściwy organ") w hiszpańskiej wersji przyjmuje formę: „Las disposiciones de la presente Directiva relativas a los regímenes de autorización se refieren a los casos en los que el acceso a una actividad de servicios o el ejercicio de la misma por parte de operadores requiere una decisión de la autoridad competente".

Analogiczne wyjątki znajdziemy w paragrafach 18, 36, 59 i 86.

Podobne niespójności dotyczą czasownika modalnego may. O ile zazwyczaj tłumaczy się go z angielskiego, stosując hiszpański czasownik poder (puede, pueden), i tutaj zdarzają się odstępstwa. Przykładowo, w paragrafie 37 angielskiemu zdaniu: "This requirement may also be fulfilled where a company is constituted for a given period or where it rents the building or installation through which it pursuits activity" odpowiada zdanie pozbawione czasownika modalnego, w trybie oznajmującym czasu teraźniejszego: „Este requisito se cumple también cuando se constituye una empresa por un plazo determinado o cuando la empresa arrienda el edificio o las instalaciones desde donde ejerce su actividad".

W tej niespójności można upatrywać skrótu myślowego, do tego będącego kalką $\mathrm{z}$ innego języka. Świadczy o tym fakt, że w kolejnym zdaniu ta sama forma (may also be fulfilled) została już przetłumaczona z użyciem czasownika modalnego poder (también puede cumplirse). Można domniemywać, że ta niekonsekwencja, powielająca się również w polskim tłumaczeniu („Wymóg ten jest również spetniony, jeżeli przedsiębiorstwo zostało założone na czas określony lub gdy wynajmuje ono budynek lub urzadzenia, które wykorzystuje do prowadzenia swojej działalności”), ma swoje źródło w wersji francuskiej („Cette exigence est également remplie lorsqu’une société est constituée pour une période donnée ou lorsqelle loue le bâtiment ou l'installation au moyen duquel elle exerce son activité").

Podobne niespójności rzadziej pojawiają się w przypadku innych czasowników modalnych, takich jak:

a) can/cannot, któremu w hiszpańskiej wersji odpowiadają formy czasownika poder [puede(n), no puede(n)];

b) need, któremu odpowiada hiszpańskie necesita $(n), h a(n)$ de lub es necesario que;

c) must i have to, którym (tak jak w przypadku should) odpowiadają formy czasowników deber lub tener que.

Warto natomiast zwrócić uwagę na jeszcze inne, poza modalnościami, możliwe niespójności pomiędzy hiszpańską i angielską wersją dyrektywy usługowej. W paragrafie 4 wersja angielska brzmi: ,Since services constitute the engine of economic growth and account for 70\% of GDP and employment in most Member States, 
this fragmentation of the internal market has a negative impact on the entire European economy...” (pol. „Ponieważ ustugi sa motorem wzrostu gospodarczego i dostarczaja $70 \%$ PKB oraz zatrudnienia $w$ większości państw członkowskich, taka fragmentacja rynku wewnętrznego wywiera niekorzystny wpływ na cała gospodarkę europejska..."), natomiast w wersji hiszpańskiej czytamy: „, A pesar de que los servicios son el motor son el motor del crecimiento económico y de que representan un 70\% del PIB y de los puestos de trabajo en la mayoría de los Estados Miembros, esta fragmentación repercute de forma negativa en el conjunto de la economía europea...", co w języku polskim oznacza: „Chociaż ustugi sq motorem wzrostu...”.

Można zatem zauważyć niespójność w logice, jaka rządzi tym zdaniem w różnych wersjach językowych. W wersji polskiej i angielskiej zauważamy bezpośrednią wynikowość: fragmentacja europejskiego rynku usług jest uznana za niekorzystną, ponieważ usługi są istotne dla wzrostu PKB i zatrudnienia. Natomiast w wersji hiszpańskiej mamy do czynienia ze zdaniem nielogicznym: fragmentacja jest niekorzystna, mimo to, że usługi są ważne. Co prawda trudno wyobrazić sobie, aby ta konkretna pomyłka w wersji hiszpańskiej mogła spowodować jakiekolwiek problemy w interpretacji dyrektywy, niemniej sytuacja mogłaby być znacznie poważniejsza, gdyby do podobnego uchybienia doszło w innym paragrafie, bardziej istotnym z punktu widzenia jej stosowania tego dokumentu prawnego.

Wszystkie wymienione przypadki niespójności między hiszpańską i angielską wersją językową dyrektywy usługowej dotyczyły wstępu do tej dyrektywy. Natomiast, jak już wcześniej odnotowaliśmy, treść właściwa dyrektywy charakteryzuje się wyraźnie większą regularnością.

Czasownikiem modalnym typowym dla tej części dyrektywy jest w wersji angielskiej shall, któremu w polskiej wersji odpowiadają formy czasu teraźniejszego czasowników zwykłych w trybie oznajmującym; w wersji francuskiej formy czasu teraźniejszego czasowników zwykłych lub czasownika posiłkowego devoir; podczas gdy $\mathrm{w}$ wersji hiszpańskiej stosuje się formy czasu przyszłego (futuro) zwykłych czasowników lub czasownika posiłkowego deber.

Artykuł 2 można potraktować jako modelowy przykład tego, jakie formy odpowiadają angielskiemu czasownikowi shall $\mathrm{w}$ trzech pozostałych wersjach językowych: ang. „This Directive shall apply to services supplied by providers established in a Member States”; pol. „Niniejsza dyrektywa ma zastosowanie do ustug świadczonych przez usługodawców prowadzacych przedsiębiorstwo w państwie członkowskim”; fr. „La présente directive s'applique aux services fourni par les prestataires ayant leur établissement dans un État membre”; hiszp. „La presente Direciva se aplicará a los servicios prestados por prestadores establecidos en un Estado miembro". 
Z kolei w paragrafach 3 i 4 artykułu 10 dostrzeżemy wykorzystanie czasownika posiłkowego devoir/deber w wersjach francuskiej i hiszpańskiej, co nie wpływa na znaczenie tych zdań, za to może świadczyć o wykorzystaniu francuskiej wersji dyrektywy przy opracowywaniu wersji hiszpańskiej: ang. „The conditions for granting authorisation for a new establishment shall not duplicate requirements and controls [...] The authorisation shall enable the provider to have access to the service activity, or to exercise that activity, throughout the national territory...”; pol. „Warunki udzielania zezwolenia na rozpoczęcie prowadzenia przedsiębiorstwa nie powielaja wymogów ani kontroli... [...] Zezwolenie zapewnia usługodawcy możliwość podjęcia lub prowadzenia działalności usługowej na całym terytorium danego państwa...”; fr. „Les conditions d'octroi de l'autorisation pour un nouvel établissement ne doivent pas faire double emploi avec les exigences et les contrôles... [...] Lautorisation doit permettre au prestataire d'avoir accès a l'activité de services ou de l'exercer sur l'ensemble du territoire national...”; hiszp. „Las condiciones de concesión de una autorización para un nuevo establecimiento no deberán dar lugar a solapamientos con los requisitos y controles... [...] La autorización deberá permitir al prestador acceder a la actividad de servicios o ejercerla en la totalidad del territorio nacional...."

Tak samo jak w wersji angielskiej konsekwentnie stosowany jest czasownik modalny shall, podobnie $\mathrm{w}$ wersji hiszpańskiej regularnie odpowiadają mu formy czasu przyszłego zwykłych czasowników lub czasownika posiłkowego deber. Czas przyszły jest stosowany w wersji hiszpańskiej także wtedy, gdy w wersji angielskiej w miejsce czasownika shall pojawia się, w drodze wyjątku, czasownik zwykły w trybie oznajmującym czasu teraźniejszego.

Przykładowo, w paragrafie 2 artykułu 3 czytamy: ang. ,This Directive does not concern rules of private international law...", natomiast wersja hiszpańska brzmi tak, jakby w angielskiej wersji zastosowano shall: hiszp. „La presente Directiva no afectará a las normas de Derecho internacional privado...".

Podobna regularność dotyczy czasownika modalnego may, tak samo jak shall typowego dla treści właściwej dyrektywy, choć występującego zdecydowanie rzadziej. Za modelowy przykład tego, jakie formy odpowiadają angielskiemu may w trzech pozostałych wersjach językowych, można potraktować paragraf 2 artykułu 16: ang. „Member States may not restrict the freedom to provide services in the case of a provider established in another Member State by imposing any of the following requierements...”, pol. „Państwa członkowskie nie mogq ograniczać swobody świadczenia ustug przez usługodawcę prowadzacego przedsiębiorstwo w innym państwie członkowskim poprzez nałożenie któregokolwiek z następujących wymogów...”, fr. „Les États membres ne peuvent pas restreindre la libre prestation de services par un prestataire établi 
dans un autre État membre en imposant l'une des exigences suivantes...”, hiszp. „Los Estados miembros no podrán restringir la libre prestación de servicios por parte de un prestador establecido en otro Estado miembro, mediante la imposición de los siguientes requisitos...”.

\section{Wnioski}

Uznawanie za równie autentyczne wszystkich wersji dokumentów prawa unijnego sporządzonych w językach narodowych państw UE rodzi ryzyko sporów interpretacyjnych. Jest ono nieuniknione $\mathrm{z}$ tego względu, że każdy język rządzi się swoimi prawami: ma typową dla siebie gramatykę, składnię, pragmatykę, słownictwo. Potencjalnie największe problemy podczas porównywania dwóch wersji językowych tego samego tekstu mogą dotyczyć wykorzystania czasowników modalnych (móc, chcieć, musieć itp.), które mają zazwyczaj odmienne, zachodzące na siebie zakresy znaczeniowe w różnych językach.

Jak pokazuje analiza angielskiej i hiszpańskiej wersji dyrektywy usługowej, praktyka translacyjna w UE zmierza jednak do wyeliminowania potencjalnych niespójności interpretacyjnych. Zwłaszcza w treści właściwej dyrektywy widać dużą regularność i odpowiedniość w stosowaniu czasowników modalnych. Typowym dla tej części dyrektywy czasownikiem angielskim jest shall, któremu odpowiadają w języku hiszpańskim formy czasu przyszłego zwykłych czasowników lub czasownika posiłkowego deber. Angielskiemu may odpowiada z kolei hiszpańskie poder w czasie przyszłym.

Osiągnięciu większej regularności w różnych wersjach językowych tych samych dokumentów unijnych sprzyja wiele czynników. Po pierwsze, język prawny charakteryzuje się dużo większą systematycznością i standaryzacją pól znaczeniowych aniżeli język potoczny. Po drugie, systemy prawne większości państw europejskich wpisują się w tę samą tradycję prawną. Po trzecie, w ramach UE zdążyła się wykształcić specyficzna nowomowa, oparta na wielu neologizmach typowych dla unijnych instytucji i transponowana w tym samym momencie do systemów prawnych poszczególnych państw.

Jednakże obok pytania technicznego o sposób radzenia sobie z potencjalnymi niespójnościami pomiędzy różnymi wersjami językowymi prawa UE w sposób nieunikniony pojawia się pytanie polityczne: czy faktycznie należy uznawać wszystkie te wersje za jednakowo autentyczne? Pytanie to nabiera w tym momencie szczególnego znaczenia $\mathrm{z}$ dwóch powodów. Po pierwsze, kryzys finansowy skłania do myślenia 
o możliwych oszczędnościach. Co prawda nawet gdyby ustanowić autentycznym tylko jeden język, dokumenty unijnego prawa nadal byłyby tłumaczone na języki państw członkowskich. Ewentualne oszczędności wynikałyby zatem z uniknięcia kosztów ewentualnych sporów interpretacyjnych i wątpliwe, aby osiągnęly istotną skalę. Natomiast kluczowy jest drugi argument: w wyniku rozszerzenia UE o dwanaście nowych państw członkowskich, w latach 2004 i 2007, umocniła się dominacja angielskiego jako języka, w którym przygotowywana jest większość roboczych tekstów prawnych i którym posługuje się większość obywateli UE. Być może to powinno przesądzić o ustanowieniu angielskiego jedynym autentycznym językiem prawa unijnego.

W tym kontekście ciekawie przedstawia się sytuacja Hiszpanii. Hiszpański jest drugim najpopularniejszym językiem na świecie, ale w Europie znajduje się poza pierwszą trójką. W sytuacji, gdy rząd Hiszpanii pilnie potrzebuje oszczędności budżetowych i zmaga się z nasilającymi się tendencjami separatystycznymi, może uznać, że wspieranie unijnej różnorodności językowej nie jest już w jego ekonomicznym i politycznym interesie. Zamiast tego może okazać się bardziej przychylny wobec pomysłu ustanowienia angielskiego jedynym autentycznym językiem UE.

Pojawienie się takiego pomysłu w bieżącej agendzie unijnej debaty politycznej wydaje się, póki co, mało prawdopodobne. Nie tylko dlatego, że państwa europejskie muszą uporać się z dużo pilniejszymi wyzwaniami, jak budowa unii bankowej, reforma strefy euro i uzgodnienie nowej wieloletniej perspektywy finansowej. Także dlatego, że w Wielkiej Brytanii coraz głośniej mówi się o rozpisaniu nowego referendum członkowskiego. A czy można wyobrazić sobie Unię, która porozumiewa się językiem angielskim, choć Wielka Brytania już do Unii nie należy?

\section{Unification of EU law and multilingualism: the case of the Spanish Language}

All versions of EU legal documents in all official EU languages are considered identical and authentic. From the theoretical point of view this may lead to interpretational arguments as each language has different grammar, word order, pragmatic and vocabulary. Potentially the greatest problems when comparing a document in two different languages may be caused by modal verbs (as have to, want, must etc.) which in different languages have different, overlapping meanings.

However, as the analysis of English and Spanish versions of the services directive of the EU proves, the translation practice of EU aims at eliminating potential 
discrepancies in interpretation. The increase in regularity in different linguistic versions of the same EU documents is helped by three factors. First, legal parlance is much more systematic and meanings are more standardized than in common language. Second, most European legal systems share common legal tradition. Third, EU managed to create a sort of "new speak” based on many neologisms characteristic of EU institutions which are introduced at the same time into legal systems of all member-states.

On the margin of the technical question, how to deal with potential discrepancies between different linguistic versions of EU law, there is also a political question: should we really consider all versions as equally identical? The papers tries to answer that question on a case study of Spanish as one of national languages of EU.

\section{Однородность права Европейского Союза и его многоязычность: казус испанского языка}

Все версии документов права Европейского Союза (ЕС) составлены на национальных языках государств-членов считаются равно аутентичными. Это, из теоретической точки зрения, возбуждает опасность возникновения споров по поводу интерпретации, вытекающих хотя бы отсюда, что каждый язык руководствуется своими правилами: у него свой синтаксис, своя грамматика, прагматика, лексика. Потенциально, самые большие проблемы во время сравнивания двух языковых версий того же самого текста, могут относится к использованию модальных глаголов (мочь, хотеть и т. п.), у которых, в разных языках, разные смысловые сферы.

Тем не менее, как показывает анализ английской и испанской версии директивы по услугам, практика перевода в ЕС направлена на элиминацию потенциальных интерпретационных несвязностей. Достижению большей регулярности в разных языковых версиях тех же самых документов ЕС способствуют особенно три фактора. Во-первых, юридический язык характеризуется на много болше систематичностю и стандартизацией смысловых полей, нежели разговорный язык. Во-вторых, правовые системы большинства европейских государств вписываются в ту же самую юридическую традицию. В-третьих, в пределах ЕС образовался специфический «новояз», основанный на многих типичных для европейских институтов неологизмах и внедряемый в правовые системы государств-членов. 
Однако, рядом с техническим вопросом, как поступать с потенциальными несвязностями в разных языковых версиях права ЕC, возникает политический вопрос: надо ли на самом деле считать все эти версии равно аутентичными? Статья является попыткой дать ответ на этот вопрос, рассматривая специфический казус испанского языка как одного из национальных языков ЕС. 